\title{
A Possible Link Between Tic Disorders Associated with Beta Thalassemia Minor and Sickle Cell Disease
}

\section{Megan Toufexis*, Adam B. Lewin, Eric A Storch, Caroline DeOleo, and Tanya K Murphy}

Department of Pediatrics, University of South Florida, USA

\begin{abstract}
Background: Genetic linkages with psychiatric disorders have been documented. In our clinical practice, we noticed a high propensity for blood disorders in female patients with certain neuropsychiatric phenomenon, specifically Tourette Syndrome (TS) or Trichotillomania (TTM). With this clinical observation, we hoped to better understand a possible genetic correlation, namely the role of chromosome 11 which encodes for both the B globulin gene and human dopamine receptor D4 (DRD4) gene.

Method: This is a retrospective case series of six children found to have a blood disorder and neuropsychiatric diagnosis in our clinic. We used family interview, lab results, and the patient's medical chart for data collection

Results: Our case series reveals six children with a repetitive neuropsychiatric disorder and a blood disorder.

Conclusions: Currently, there are no definitive susceptibility genes that have been identified to date for TS or TTM. We postulate that blood disorders found on chromosome 11 may play a role as a susceptibility factor, particularly in females, for repetitive neuropsychiatric disorders.
\end{abstract}

Keywords: Tourette syndrome; Tics; Trichotillomania; Sickle cell trait; Beta thalassemia minor

\section{Introduction}

The aim of this report is to describe a possible genetic link between tic disorders and trichotillomania, and blood disorders as they may have a common link associated with chromosome 11. We present six cases of school-aged children (4 females) who had one of these repetitive psychiatric disorders and a blood disorder of either beta thalassemia minor or sickle cell trait. This report builds on the existing literature which has identified genetic links and familial overlap between obsessive compulsive spectrum disorders and blood disorders. Identification of the etiological factors of these disorders will lead to a greater understanding of their pathogenesis and treatment options.

\section{Background}

Psychiatric disorders, like many other medical disorders have potential genetic links. Obsessive compulsive spectrum disorders, such as Obsessive Compulsive Disorder (OCD), tics, and trichotillomania (TTM) may share a common genetic susceptibility as many studies cite high rates of familial overlap [1]. Once presumed rare, the prevalence of Tourette syndrome (TS) is now estimated to range between, 1 to 10 per 1000, in school-aged children and across all ethnic groups with males affected about three to four times more often than females [2]. OCD is a common co morbid condition found in patients with tics with prevalence in adolescents reported to be between 2 to $3 \%$. The lifetime prevalence of TTM is between 1 to $3 \%[3,4]$. TTM is similarly related to OCD and TS as these disorders can involve a negative reinforcement paradigm in which there is a premonitory urge and temporary relief after completion of an action.

In the United States it is estimated that two million people have thalassemia trait, either alpha or beta [5], and sickle cell trait is found in 7 to 9 African Americans [6]. Beta thalassemia minor and sickle cell trait (HbSC) often present with anemia that is mistakenly thought to have little clinical significance to overall health of the affected individual. Chromo-some 11 encodes a gene specific for B globulin, "Hemoglobin Beta" or the HBB gene, which are both affected in beta thalassemia minor and sickle cell disease. In beta thalassemia minor, the production of the beta chain is affected resulting in mild-to-moderate microcytic anemia. Sickle Cell Disease (SCD) produces a mutant form of beta globulin, due to a point mutation at the sixth position of its beta chain, in which glutamic acid is replaced with valine. This mutation results in a sickled, incorrectly functioning red blood cell (RBC). The sickle cell trait form of the disease (HbSC) occurs when only one of the hemoglobin genes is sickled. The HBB gene is located at 11p15.5 and more precisely from base pair 5,203,271 to base pair 5,204,876 (Figure $1)$.

Chromosome 11 has been implicated as having a linkage associated with multiple psychiatric disorders such as Attention Deficit Hyperactivity Disorder (ADHD), Tourette syndrome, and bipolar disorder. Over the past 10 years there have been several studies indicating there may be a link between chromosome 11q 23 24 and Tourette syndrome [7]. The human dopamine receptor D4

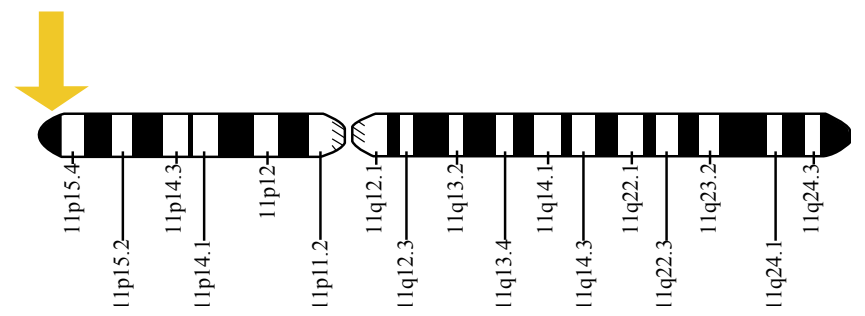

Figure 1: HBB gene is located at $11 \mathrm{p} 15.5$ and more precisely from base pair $5,203,271$ to base pair $5,204,876$.

*Corresponding author: Megan Toufexis, DO, Assistant Professor of Pediatrics, Department of Pediatrics, University of South Florida, $8806^{\text {th }}$ Street South, Suite 460 Box 7523, St. Petersburg, FI 33701, USA, Tel: 727-767-8230; Fax: 727-767-7786; E-mail: mtoufexi@usf.health.edu

Received October 01, 2012; Accepted January 06, 2013; Published January 08, 2013

Citation: Toufexis M, Lewin AB, Storch EA, DeOleo C, Murphy TK (2013) A Possible Link Between Tic Disorders Associated with Beta Thalassemia Minor and Sickle Cell Disease. J Clin Case Rep 3:244. doi:10.4172/2165-7920.1000244

Copyright: (c) 2012 Toufexis M, et al. This is an open-access article distributed under the terms of the Creative Commons Attribution License, which permits unrestricted use, distribution, and reproduction in any medium, provided the original author and source are credited. 
(DRD4) gene like the HBB gene is located on chromosome 11p15.5. This dopamine gene has been found to be specifically located from base pair 637,304 to base pair 640.705. The DRD4 gene is one of the most variable human genes known and has been linked to multiple psychiatric disorders such as ADHD, a common co morbid diagnosis with TS, and impulse control disorders such as TTM [8].

Minor or heterozygote blood disorders are not necessarily benign and are a source of controversy in the medical literature. Some view the trait form of the disease as a milder or intermediary form of sickle cell disease but each have their own medical complications. Sickle cell disease patients are at an increased risk of bacteremia particularly from encapsulated organisms, splenic sequestration, vaso-occlusive crisis, stroke, renal disease, and pulmonary hypertension [9]. Sickle cell trait (HBSC) has been associated with sudden idiopathic death/ and or rhabdomyolysis during intense exercise, splenic infarctions at elevated altitudes, hematuria, hyposthenuria, bacteriuria, and renal medullary carcinoma in children and young adults [10]. Minor hemoglobinopathies have been linked to have a higher prevalence of asthma [11]. Cognitive dysfunction has been linked to various anemias and more specifically an association between low hemoglobin and neurocognitive impairment has been found in children with sickle cell disease [12].

\section{Case Reports}

Case A is an 11-year-old female diagnosed with TS, ADHDcombined type, and remitted OCD. At the age of 10 years her tics became so severe that a pediatric neurologist diagnosed her with Sydenham chorea, a movement disorder caused by Group A Streptococcus. Her tics consisted of wiggling her nose, head bobbing, grunting and a need to straighten out her arms. She has beta thalassemia minor with anemia and the patient's maternal grandmother and mother also have beta thalassemia minor. She is of Sicilian descent from her mother who is second generation Sicilian and father is from Honduras. There is no history of anemia on the father's side of the family. A maternal uncle has TS and her father has unspecified tics.

Case B is a 13-year-old female diagnosed with TS at the age of 12 years. Her parents report that they had concerns of tic behaviors since she was a young child but only sought treatment after the tics became impairing. Her tics consisted of grunting, throat clearing, and neck, leg and arm jerking. She has both alpha thalassemia minor and beta thalassemia minor. Her mother is known to have alpha thalassemia minor and is of European and Cherokee descent. The father's history is unknown as this patient was conceived thru insemination.

Case $\mathrm{C}$ is a 7-year-old African/American/Caucasian female diagnosed with ADHD-combined type, OCD, and Chronic Motor Tic Disorder. Her symptoms consisted of being impulsive, hyperactive, distractible and making disruptive noises at times. She preferred to do things in sets of three and was perfectionist in her homework, erasing letters up to 50 times until they look right to her. Her tics consisted of head and jaw movements. She has sickle cell trait and a family history of blood disorders was not obtainable due to patient being lost to follow-up.

Case $\mathrm{D}$ is a 17-year-old Caucasian female diagnosed with Trichotillomania, Major Depressive Disorder and Generalized Anxiety Disorder. She began to pull hair from her scalp and eyebrows when she was 12 years-old. She has beta thalassemia minor, which was inherited from her father.

Case $\mathrm{E}$ is an 8-year-old African American boy diagnosed with TS and ADHD-combined type. He began having vocal tics in kindergarten which lasted a few months. Motor tics began at age 8 and consisted of eye blinking, eye rolling and neck jerks. He has sickle cell trait which was inherited from his father who is of Sicilian descent. His family history is significant for a paternal uncle with ADHD and tic disorder.

Case $\mathrm{F}$ is an 8-year-old African American boy diagnosed with transient tic disorder. He developed a neck jerking tic concurrent with a GAS infection that remitted after a few months. He has sickle cell trait, which his mother, sister and maternal grandmother also have. There is no family history of a tic disorder (Table 1).

\section{Discussion}

We present a case series of children diagnosed with a repetitive neuropsychiatric disorder such as tics, OCD, or hair pulling also diagnosed with beta thalassemia minor or sickle cell trait. It is possible that having one of these blood disorders was an incidental finding or that these disorders had a contributory role in developing TS or TTM. It is interesting that four of the six cases were female whereas tic disorders are much less commonly represented compared with males. The $15 \mathrm{p} .5$ area on chromosome 11 is a highly imprinted area and could possibly explain the greater incidence of females in this case series. Many studies of families have indicated a greater risk of developing TS in first degree relatives compared to the general population [13] yet only two of our 6 cases had a reported family history of a tic disorder. Only one of our cases (F) had a sibling, a sister, with the same hemoglobinopathy but did not have any psychiatric diagnosis. The concurrent hematological carrier state may increase risk for neuropsychiatric illness expression such as tics and trichotillomania or perhaps some other unknown factor contributed to a greater risk for both.

Research supports overlapping co morbidities of TTM, ADHD, tic disorder, anxiety, impulse control disorders, and mood disorders [14] A recent genetic study of families with TS found there may be a heritable phenotype with those that had a combination of TS, OCD, and ADHD [15]. A 2008 study of 133 adolescents identified with a primary diagnosis of TTM found that $38.3 \%$ had co-morbid psychiatric diagnoses. The most common were anxiety disorder (24.1\%), mood disorder (18.8\%), attention-deficit disorder with or without hyperactivity (16.5\%), and tic disorder (4.5\%) [16].

Chromosome 11 has been implicated to have a linkage associated with multiple psychiatric disorders such as ADHD, Tourette syndrome, impulse control disorders, and bipolar disorder. Over the past 10 years there have been several studies indicating there may be a link between

\begin{tabular}{|l|l|l|l|l|l|l|}
\hline Cases & A & B & C & D & E & F \\
\hline Age & 11 & 13 & 7 & 17 & 8 & 8 \\
\hline Gender & Female & Female & Female & Female & Male & Male \\
\hline Psychiatric DX & $\begin{array}{l}\text { TS } \\
\text { OCD } \\
\text { ADHD }\end{array}$ & TS & $\begin{array}{l}\text { ADHD } \\
\text { OCD } \\
\text { CMT }\end{array}$ & $\begin{array}{l}\text { TTM } \\
\text { MDD }\end{array}$ & $\begin{array}{l}\text { TS } \\
\text { GAD }\end{array}$ & TTD \\
\hline Blood disorder & BTM & A/BTM & HbSC & BTM & HbSC & HbSC \\
\hline Family member w/BD & Mother, & Mother & unknown & Father & Father & Mother \\
& MGM & MGM, S \\
\hline Family history of Tics & Yes & No & No & No & Yes & No \\
\hline
\end{tabular}

ADHD: Attention Deficit Hyperactivity Disorder; A/BTM: Alpha and Beta Thalassaemia Minor; BD: Blood Disorder; BTM: Beta Thalassaemia Minor; CMT: Chronic Motor Tic; GAD: Generalized Anxiety Disorder; HbSC: Sickle Cell Trait; MD: Major Depression; MGM: Maternal Grandmother; OCD: Obsessive Compulsive Disorder; S: Sister; TTD: Transient Tic Disorder; TTM: Trichotillomania; TS: Tourette Syndrome

Table 1: Characteristics of the patients. 
chromosome 11q 23-24 and TS. Dopaminergic abnormalities in frontal-sub cortical circuits have been hypothesized as the underlying pathophysiological mechanism in TS, impulse control disorders, and ADHD. Recently, a certain dopamine receptor, found on the DRD4 gene, which is located in chromosome $11 \mathrm{p} 15.5$, has also been linked to ADHD. In addition, chromosome 11 has also been linked with bipolar disorder [17] and multiple case reports discuss a possible linkage between bipolar disorder and Beta Thalassemia minor [18,19].

In addition, $\mathrm{ADHD}$ is often a common co morbid diagnosis found with TS and OCD and has significant impact in academics and intellectual function. Cognitive dysfunction has been linked to various anemias, and three out of the six cases were diagnosed with ADHD combined type. Cognitive dysfunction in areas such as sustained attention, executive function, coordination, and visual motor speed are found to be impaired in children who have subclinical or silent strokes which are common complications of SCD. These infarctions can appear on MRI without any history of a neurological event [20] and have a prevalence rate in children with the HBSS form between $20 \%$ to $25 \%$ [21].

Another study compared cognitive processing and academic functioning in both HBSS and HBSC with non-diseased siblings and found significantly lower scores in both HBSS and HBSC of sickle cell disease compared to their siblings [22]. A study from 2007 reported cognitive dysfunction in adult patients with beta-thalassemia minor by evaluating event related potentials. Patients with beta thalassemia minor had P300 latency that was significantly longer than in the control group and had lower amplitudes, suggestive of cognitive dysfunction [23]. These studies argue that the minor forms of both hemoglobinopathies should not be overlooked as medical diagnoses with little or few clinical repercussions.

This case review was intended to increase understanding between the localization of a gene or genes involved in the expression of TS and TTM. Four of our six cases had no clear genetic history of a neuropsychiatric disorder and these specific cases suggest that blood disorders might play a role as a susceptibility factor in obsessive compulsive spectrum disorders, specifically tic disorders and trichotillomania. With the low prevalence of females reported in the literature with TS, this additional dysfunction of the beta globulin gene on chromosome 11 may add a predisposing risk factor for females to develop these disorders. We also suggest that with the well established findings of cognitive dysfunction in patients with sickle cell disease and thalassemias that many children with just the trait form of each disease may be having cognitive dysfunction secondary to the hematologic disease which needs to be further explored.

There are many limitations to our study such as the small sample size, missing family medical and psychiatric data, lack of genetics and neuro-imaging. Potential considerations for future research include: a) replication surveys of microcytic anemia and the thalassaemic trait in psychiatric populations from high prevalence areas; b) surveys of tic disorder and impulse control disorders among subjects with an already established diagnosis of heterozygous $\beta$-thalassemia or sickle cell anemia and; c) family studies of patients with TS and TTM and an established thalassaemic trait; d) genetic microarrays; and e) imaging that would examine cerebral vasculopathy in children, such as transcranial doppler ultrasonography. This imaging could aid in determining what effects compromised red blood cells have neurologically as there is little literature examining this. A future prospective study examining children with tic disorder and blood disorder versus a control population of children with only tic disorder is warranted.

\section{References}

1. Grados MA, Riddle MA, Samuels JF, Liang KY, Hoehn-Saric R, et al. (2001) The familial phenotype of obsessive-compulsive disorder in relation to tic disorders: the Hopkins OCD family study. Biol Psychiatry 50: 559-565.

2. Scahill L, Sukhodolsky DG, Williams SK, Leckman JF (2005) Public health significance of tic disorders in children and adolescents. Adv Neurol 96: 240248.

3. King RA, Scahill L, Vitulano LA, Schwab-Stone M, Tercyak KP Jr, et al. (1995) Childhood trichotillomania: clinical phenomenology, comorbidity, and family genetics. J Am Acad Child Adolesc Psychiatry 34: 1451-1459.

4. Zohar AH (1999) The epidemiology of obsessive-compulsive disorder in children and adolescents. Child Adolesc Psychiatr Clin N Am 8: 445-460.

5. Northern California (2005) Comprehensive Thalassemia Center.

6. Derebail VK, Nachman PH, Key NS, Ansede H, Falk RJ, et al. (2010) High prevalence of sickle cell trait in African Americans with ESRD. J Am Soc Nephrol 21: 413-417.

7. Miranda DM, Wigg K, Feng Y, Sandor P, Barr CL (2008) Association study between Gilles de la Tourette Syndrome and two genes in the Robo-Slit pathway located in the chromosome 11q24 linked/associated region. Am J Med Genet B Neuropsychiatr Genet 147B: 68-72

8. McCracken JT, Smalley SL, McGough JJ, Crawford L, Del'Homme M, et al (2000) Evidence for linkage of a tandem duplication polymorphism upstream of the dopamine D4 receptor gene (DRD4) with attention deficit hyperactivity disorder (ADHD). Mol Psychiatry 5: 531-536.

9. Ashley-Koch A, Yang Q, Olney RS (2000) Sickle hemoglobin (HbS) allele and sickle cell disease: a HuGE review. Am J Epidemiol 151: 839-845.

10. Key NS, Derebail VK (2010) Sickle-cell trait: novel clinical significance. Hematology Am Soc Hematol Educ Program 2010: 418-422.

11. Palma-Carlos AG, Palma-Carlos ML, Costa AC (2005) "Minor" hemoglobinopathies: a risk factor for asthma. Eur Ann Allergy Clin Immunol 37: 177-182.

12. Kral MC, Brown RT, Connelly M, Curé JK, Besenski N, et al. (2006) Radiographic predictors of neurocognitive functioning in pediatric Sickle Cell disease. J Child Neurol 21: 37-44.

13. Pauls DL, Raymond CL, Stevenson JM, Leckman JF (1991) A family study of Gilles de la Tourette syndrome. Am J Hum Genet 48: 154-163.

14. Grados MA, Mathews CA (2009) Clinical phenomenology and phenotype variability in Tourette syndrome. J Psychosom Res 67: 491-496.

15. Grados MA, Mathews CA; Tourette Syndrome Association International Consortium for Genetics (2008) Latent class analysis of gilles de la tourette syndrome using comorbidities: clinical and genetic implications. Biol Psychiatry 64: $219-225$.

16. Franklin ME, Flessner CA, Woods DW, Keuthen NJ, Piacentini JC, et al (2008) The child and adolescent trichotillomania impact project: descriptive psychopathology, comorbidity, functional impairment, and treatment utilization. J Dev Behav Pediatr 29: 493-500.

17. Egeland JA, Gerhard DS, Pauls DL, Sussex JN, Kidd KK, et al. (1987) Bipolar affective disorders linked to DNA markers on chromosome 11. Nature 325: 783787.

18. Harada H, Nakajima T, Inazawa J, Abe T (1995) Bipolar affective disorder associated with beta-thalassemia minor. Biol Psychiatry 37: 477-479.

19. Bocchetta A (2005) Heterozygous beta-thalassaemia as a susceptibility factor in mood disorders: excessive prevalence in bipolar patients. Clin Pract Epidemiol Ment Health 1: 6 .

20. Schatz J, Finke RL, Kellett JM, Kramer JH (2002) Cognitive functioning in children with sickle cell disease: a meta-analysis. J Pediatr Psychol 27: 739748.

21. Wills KE, Nelson SC, Hennessy J, Nwaneri MO, Miskowiec J, et al (2010) Transition planning for youth with sickle cell disease: embedding neuropsychological assessment into comprehensive care. Pediatrics 126 S151-159. 
Citation: Toufexis M, Lewin AB, Storch EA, DeOleo C, Murphy TK (2013) A Possible Link Between Tic Disorders Associated with Beta Thalassemia Minor and Sickle Cell Disease. J Clin Case Rep 3: 244. doi:10.4172/2165-7920.1000244

Page 4 of 4

22. Brown RT, Buchanan I, Doepke K, Eckman JR, Baldwin K, Goonan B, et al. (1993) Cognitive and Academic Functioning in Children With Sickle-Cell Disease. Journal of Clinical Child Psychology 22: 207-218.
23. Nevruz O, Ulas U, Cetin T, Kutukcu Y, Kurekci A (2007) Cognitive dysfunction in beta-thalassemia minor. Am J Hematol 82: 203-207. 